\title{
Los Convenios Urbanísticos en Andalucía
}

\author{
Guillermo Lago Núñez \\ Secretario General \\ Ayuntamiento de Roquetas de Mar (Almería)
}

Resumen:

Pese a que los Convenios han tenido un importante papel en la gestión urbanística, no se puede obviar que la figura de los Convenios urbanísticos tiene cierto componente negativo al haber servido, en determinadas ocasiones, únicamente como instrumento para la reclasificación o recalificación de determinados ámbitos.

En este trabajo, tras sintetizarse los antecedentes que existen en el ordenamiento jurídico español, planteamos una postura positiva hacía los convenios, ya sea en su vertiente interadministrativa o entre la Administración y los particulares a la luz de la vigente legislación, al configurarse como una fórmula consensuada o de cooperación voluntaria para la solución de los conflictos que se generan en una organización compleja como es la ciudad.

También se analiza las relaciones entre los Contratos y los Convenios, en especial ante la reciente incorporación de los Convenios interadministrativos que tengan por objeto un contrato administrativo, a raíz de las directivas europeas, en la legislación de contratos de Administraciones Públicas.

Palabras clave:

Convenios urbanísticos. Convenios interadministrativos. Planeamiento urbanístico. Gestión Urbanística. Contratos administrativos especiales.

SUMARIO: Abreviaturas utilizadas. I. INTRODUCCIÓN. II. ANTECEDENTES DE LA FIGURA. 1. Evolución legislativa. 2. Evolución jurisprudencial. 3Evolución práctica. III. CONCEPTO. NATURALEZA JURIDICA. 1. Concepto. 2. Naturaleza jurídica. 2.1. De los Convenios interadministrativos. 2.2. De los Convenios entre la Administración y particulares. 3. Algunas consideraciones sobre la aplicación del régimen contractual a los Convenios urbanísticos. 3.1. La incidencia de la legislación de contratos en la legislación urbanística.3.2. Las garantías del cumplimiento de los Convenios. IV. RÉGIMEN JURÍDICO. LOS PRINCIPIOS DE TRANSPARENCIA Y PUBLICIDAD. V. TIPOLOGÍA DE LOS CONVENIOS INTERADMINISTRATIVOS ENTRE DOS 
O MÁS ADMINISTRACIONES PÚBLICAS. 1. Convenios interadministrativos para la prestación de la asistencia técnica y administrativa en materia de ordenación urbanística. 2. Convenios interadministrativos para la gestión patrimonial. 3. Convenios interadministrativos de planeamiento. 4. Convenios interadministrativos para la ejecución. Consorcios. 5. Convenios interadministrativos para la Gestión Integrada. 6. Convenios interadministrativos para la ejecución de actuaciones de interés autonómico. VI. TIPOLOGÍA DE LOS CONVENIOS ENTRE LA ADMINISTRACIÓN Y LOS PARTICULARES. 1. Convenio urbanístico de planeamiento. 1.1. Convenio para la formación de instrumentos de planeamiento. 1.2. Convenio para la innovación de instrumentos de planeamiento. 2. Convenio urbanístico de gestión. 2.1. Convenio para la determinación del sistema de actuación y forma de gestión. 2.2. Convenio para la sustitución del sistema de actuación por compensación. 2.3. Convenio para la terminación del procedimiento de declaración de incumplimiento del sistema de actuación por compensación. 2.4. Convenio relativo a la asunción de gastos de urbanización. 2.5. Convenio para el pago en especie del justiprecio en el sistema de expropiación. 2.6. Convenio para la adjudicación de la actuación urbanizadora al agente urbanizador. 2.7. Convenio para la fijación de las Bases del Sistema de Cooperación. 2.8. Convenio para el aplazamiento de pago de urbanización en el sistema de Cooperación. 2.9. Convenio por el que se establece procedimientos sustitutorios al pago en metálico del precio de la ejecución de obras. 2.10. Convenio para el establecimiento del sistema de compensación. 2.11. Convenio para la sustitución de las cesiones patrimoniales por pago en metálico. 2.12. Convenio para la cesión gratuita de dotaciones. VII. CONSIDERACIONES FINALES BIBLIOGRAFÍA

\section{ABREVIATURAS UTILIZADAS}

AGE: Administración General del Estado

art.(s): artículo(s)

BOP: Boletín Oficial de la Provincia

CCAA: Comunidades Autónomas.

EELL: Entidades Locales

CE: Constitución Española de 1978.

CEE: Comunidad Económica europea.

LBRL: Ley 7/1985, de 2 de abril, reguladora de las Bases de Régimen Local. LCAP: Real Decreto Legislativo 2/2000, de 16 de junio, por el que se aprueba el texto refundido de la Ley de Contratos de las Administraciones Públicas.

LEF: Ley de 16 de diciembre de 1954, de Expropiación forzosa

LJCA: Ley 29/1998, de 13 de julio, reguladora de la Jurisdicción Contencioso-administrativa. 
LOFAGE: Ley 6/1997, de 14 de abril, de Organización y Funcionamiento de la Administración General del Estado.

LOTA: Ley 1/1994, de 11 de enero, de Ordenación del Territorio de la Comunidad Autónoma de Andalucía.

LPAP: Ley 33/2003, de 3 de noviembre, de Patrimonio de las Administraciones Públicas.

LJCA: Ley 29/1998, de 13 de julio, reguladora de la Jurisdicción Contencioso-administrativa.

LRJAP: Ley 30/1992, de 26 de noviembre, de Régimen Jurídico de las Administraciones Públicas y del Procedimiento Administrativo Común.

LSOU: Ley sobre régimen de suelo y ordenación urbana aprobada por la Ley de 12 de mayo de 1956

LRSOU: Ley sobre Régimen de Suelo y Ordenación Urbana. Texto Refundido aprobado por Real Decreto 1346/1976, de 9 de abril.

TRRL: Real Decreto Legislativo 781/1986, de 18 de abril, por el que se aprueba el Texto refundido de las disposiciones legales vigentes en materia de régimen local.

TRRSOU: Real Decreto Legislativo 1/1992, de 26 de junio, por el que se aprueba el Texto Refundido de la Ley sobre Régimen de Suelo y Ordenación Urbana.

LRSV: Ley 6/1998, de 13 de abril, de Régimen Jurídico del Suelo y Valoraciones.

PGOU: Plan General de Ordenación Urbana (Urbanística)

PMS: Patrimonio Municipal del Suelo

PPS: Patrimonio Público del Suelo

RD: Real Decreto

STC: Sentencia del Tribunal Constitucional

STS: Sentencia del Tribunal Supremo

SSTS: Sentencias del Tribunal Supremo.

SUE: Suelo Urbanizable

SUENP: Suelo urbanizable no programado (suelo urbanizable sectorizado)

SNU: Suelo No Urbanizable.

TC: Tribunal Constitucional

TRRL: Real Decreto Legislativo 781/1986 de 18 de abril, por el que se aprueba el Texto Refundido de las Disposiciones legales vigentes en materia de Régimen local.

TSCE: Tribunal Superior de Justicia de la Comunidad europea.

TS: Tribunal Supremo.

TSJ: Tribunal Superior de Justicia.

VPO: Vivienda de Protección Oficial. 


\section{INTRODUCCIÓN}

Tanto la cooperación y colaboración de las Administraciones Públicas en el ejercicio de la actividad urbanística, como la participación ciudadana y la colaboración de la iniciativa privada para un más eficaz desarrollo de esta función pública han venido siendo recogidas en todas las normas urbanísticas que se han ido aprobando en nuestro ordenamiento jurídico ${ }^{1}$.

La mayor parte de estas colaboraciones se han materializado a través de los denominados Convenios urbanísticos que han surgido en la práctica de la actuación urbanística, en los cuales, de forma ya sea convencional o contractual, se han ido recogiendo los compromisos que adquiría cada parte en función de las potestades, derechos y deberes que les iba atribuyendo en cada momento la legislación urbanística.

El propósito de este trabajo es centrar, desde la perspectiva de la LOUA, la figura del Convenio Urbanístico en sus distintas modalidades y tipologías, examinado los antecedentes no solo legales y jurisprudenciales sino también los derivados de la propia praxis.

Si es cierto que, en la práctica, ni los poderes públicos han conducido los procesos urbanísticos, ni los planes han venido cumpliendo las funciones que les corresponden, al atribuirse esta misión, de facto, a los convenios urbanísticos, a los que han seguido, de inmediato, las correspondientes y múltiples modificaciones puntuales de planeamiento ${ }^{2}$, también lo es, como acertadamente ha señalado T.R. FERNÁNDEZ, que estos instrumentos "contribuyen a asegurar una mayor transparencia a los procesos de negociación de soluciones y fórmulas de equilibrio", en situaciones complejas, ya que "la relación Administración-administrado no es hoy la de sujeción, afín a la posición de súbdito, sino de ciudadano al que corresponde una actividad y ostenta unos intereses, cuya satisfacción, en lo compatible con el interés público, puede y debe atender la Administración ${ }^{3 "}$.

${ }^{1}$ LSOU: art. 4; LRSOU: art. 4.1 y art. 234; TRRSOU: art. 4; LRSV: art. 4. LOUA: art. 5.

${ }^{2}$ Juan Antonio ÁLVAREZ MARTÍN. "Sobre la naturaleza y régimen jurídico de las licencias urbanísticas”. El Consultor de los Ayuntamientos y Juzgados no 4 4/2002.

${ }^{3}$ Jerónimo AROZAMENA SIERRA "Algunas consideraciones sobre la institución contractual y el urbanismo: los llamados Convenios Urbanísticos”. Revista de Derecho Urbanístico y Medio Ambiente $\mathrm{n}^{\mathrm{o}}$ 146/1995. 


\section{ANTECEDENTES DE LA FIGURA}

\section{1.- Evolución legislativa}

En el Ordenamiento jurídico español se menciona por primera vez a los Convenios urbanísticos, exclusivamente en orden a fijar la jurisdicción a la que han de someterse, en el art. 222 de la LSOU de 12 de mayo de 1956, al señalar que: «Tendrán carácter jurídico-administrativo todas las cuestiones que se suscitaren con ocasión o como consecuencia de los actos y convenios regulados en la presente Ley entre la Comisión de Urbanismo o las Corporaciones locales, y los propietarios, individuales o asociados o Empresas urbanizadoras, incluso las relativas a cesiones de terrenos para urbanizar o edificar».

Este precepto es recogido posteriormente en el art. 234 del LRSOU de 9 de abril de 1976 así como en el art. 303 el TRRSOU de 26 de junio de 1992, el cual ha sido declarado expresamente vigente por la disposición derogatoria única de la LRSV de 13 de abril de 1998 que no regula expresamente esta materia.

Por otra parte la LRSOU permitió, con determinados condicionamientos, la iniciativa y colaboración de los particulares en el planeamiento en una serie de disposiciones entre las que se consignan "los compromisos que se hubieran de contraer entre el urbanizador y el Ayuntamiento y entre aquél y los futuros propietarios de solares" 4 , los cuales sirvieron por vía convencional, para acercar posiciones y armonizar intereses, que en aras de la transparencia del mercado de suelo y garantía, debían hacerse constar en las enajenaciones de terrenos de urbanizaciones de iniciativa privada, tanto "los compromisos con los adquirentes" como "los que el propietario hubiera asumido y cuyo cumplimiento esté pendiente" 5 .

En el marco jurídico administrativo junto a la admisibilidad de la figura del Convenio -y de los compromisos que se hubieran de contraer - se establecieron otras formas de negociación con la iniciativa privada mediante las actuaciones denominadas "Programas de Actuación urbanística"6 en la que se

\footnotetext{
${ }^{4}$ LRSOU: Art. 105.2 d).

${ }^{5}$ LRSOU: Art. 45.

${ }^{6}$ Estas técnicas de actuaciones concertadas llegan al campo del Urbanismo según Paulino MARTÍN HERNÁNDEZ, procedentes de la planificación económica. El III Plan de Desarrollo Económico y Social aprobado por la Ley 22/1972, estableció la posibilidad de convocar concursos públicos para conseguir determinados objetivos urbanísticos: preparación de suelo para la edificación, construcción de viviendas, dotación de equipamientos e instalaciones productivas, do-
} 
aplicaban técnicas contractuales, concertadas, para integrar la iniciativa privada en el sistema de planificación indicativa ${ }^{7}$, dentro de los suelos urbanizables no programados.

En todo caso, en estos momentos, forma parte de la Legislación estatal, por lo que respecta a la legislación del suelo la siguiente disposición:

“Art. 303. Competencias de la jurisdicción contenciosa.- Tendrán carácter jurídico-administrativo todas las cuestiones que se suscitaren con ocasión o como consecuencia de los actos y convenios regulados en la legislación urbanística aplicable entre órganos competentes de las Administraciones Públicas y los propietarios, individuales o asociados o empresas urbanizables, incluso las relativas a las cesiones de terrenos para urbanizar o edificar".

Por su parte, en el ámbito foral y autonómico, se viene considerando que en su configuración propia aparece por primera vez en el Derecho foral de Navarra mediante la Ley Foral n⿳ $10 / 1994$, de 4 de julio de Ordenación del Territorio y del Urbanismo, y, posteriormente en el Derecho urbanístico madrileño al recogerse el art. 74 y concordantes de la Ley 9/1995, de 28 de marzo, de medidas de Política Territorial, Suelo y Urbanismo ${ }^{8}$, hoy recogido en el art. 243.1 de la Ley 9/2001, de 17 de julio, de Suelo de la Comunidad de Madrid.

Hoy los Convenios urbanísticos cuentan con regulación , junto con los expresados de las Comunidades autónomas de Navarra y Madrid, en las de Andalucía, Aragón ${ }^{9}$, Asturias ${ }^{10}$, Canarias ${ }^{11}$, Cantabria ${ }^{12}$, Castilla-La Mancha ${ }^{13}$,

centes y de asistencia social, cuyo antecedentes son las zonas de "amenagement concerté" (ZAC) a que se refiere el Código de Urbanismo francés y las "convenzione edilizia” del Derecho italiano.

${ }^{7}$ La naturaleza de los PAU's ha sido muy controvertida por la doctrina. Para LOPEZ PELLICER se trata de un Convenio, al ser un proceso de naturaleza mixta en el que existen factores o elementos de voluntariedad, un cierto pacto entre la Administración y los administrados pero también ulteriores consecuencias. Para T.R. FERNÁNDEZ, se trata de una relación concesional. LEIVA, por su parte afirma que se trata de un contrato administrativo especial.

${ }^{8}$ No obstante la Ley valenciana 4/1992, de 5 de junio, de suelo no urbanizable, introdujo en su Art., 4 la figura de los Convenios con finalidad urbanística en estos suelos.

${ }^{9}$ Ley 5/1999, de 25 de marzo: art. 84.

${ }^{10}$ Ley 3/2002, de 19 de abril: art. 156-160.

11 Decreto legislativo 1/2000, de 8 de mayo: art. 109.

12 Ley 2/2001, de 25 de junio: art. art. 262.

${ }^{13}$ Ley 2/1998, de 4 de junio modificada por Ley 1/2003, de 17 de junio 
Castilla-León ${ }^{14}$, Cataluña ${ }^{15}$, Extremadura ${ }^{16}$, Galicia $^{17}$, La Rioja ${ }^{18}$, Murcia $^{19}, y$ Valencia $^{20}$.

En Andalucía la LOUA regula expresamente la figura del Convenio urbanístico en su doble vertiente, entre Administraciones Públicas, o entre éstas y privados (art. 30 y 95), siendo su finalidad, según la Exposición de Motivos (VII): "tanto la de establecer los términos de colaboración como la de procurar un más eficaz desarrollo de la gestión urbanistica", si bien no podrán "en ningún caso, condicionar la función pública de la actividad urbanística, debiendo quedar salvaguardada la integridad de la potestad de planeamiento, y quedando sujetos a los principios de transparencia y publicidad".

\section{Evolución Jurisprudencial}

La escasez de preceptos que regulaban los Convenios ha provocado que su desarrollo se haya efectuado al borde de la legalidad ${ }^{21}$ y que, por tanto, sea la jurisprudencia, a partir de estas escasas e incompletas referencias normativas, la que ha perfilado y delimitado la institución. En este sentido los Tribunales de Justicia, aunque se pronunciaron al principio radicalmente contrarios a la disposición negocial de las competencias públicas, tal y como se expresa en la STS de 30 de abril de 1979, posteriormente, y durante este período de casi cincuenta años, han ido decidiendo, caso por caso, si los convenios no invadía competencias indisponibles y si se daba el interés público al que deben servir las Administraciones Públicas con objetividad que legitimara esta forma de proceder al aparecer muchos casos en los que quedaban desvirtuados. En este sentido se ha venido citando como ejemplo la STS de 30 abril 1990 (Ponente: Delgado Barrio):

${ }^{14}$ Ley 5/1999, de 8 de abril: art. 99.

${ }^{15}$ Ley 2/2002, de 14 de marzo: art. 129-132.

${ }^{16}$ Ley 15/2001, de 14 de diciembre: art. 48 y 114.

${ }^{17}$ Ley 10/1995, de 23 de noviembre: art. 6, art. 16, art. 19.

${ }^{18}$ Ley 10/1998, de 2 de julio: art. 148-150.

${ }^{19}$ Ley $1 / 2001$, de 24 de abril: art. 158.

${ }^{20}$ Ley 4/1992, de 5 de junio: disposición adicional cuarta, y disposición adicional sexta de la Ley $6 / 1994$, de 15 de noviembre.

${ }^{21}$ M REBOLLO RUIZ y R. PIZARRO NEVADO "Ejecución de planeamiento. Los Convenios urbanísticos". 
«Segundo. — La diversidad de intereses presentes en el campo del urbanismo hacen de la de planeamiento una potestad de titularidad compartida por los Municipios y las Comunidades Autónomas. Su actuación se lleva a cabo a través de un procedimiento bifásico en el que a la aprobación provisional del Municipio, en lo que ahora importa, sigue en el tiempo la definitiva de la Administración Autonómica. Partiendo de la base de que "en la relación entre el interés local y el interés supralocal es claramente predominante este último" — sentencia del TC 170/1989, de 19 de octubre - queda perfectamente justificado que, en el aspecto temporal, la decisión autonómica se produzca con posterioridad a la municipal y que, en el aspecto sustantivo, aquélla haya de contemplar el plan no sólo en sus aspectos reglados sino también en los discrecionales que por su conexión con intereses supralocales hayan de ser valorados para asegurar una coherencia presidida por la prevalencia de tales intereses superiores. Sobre esta base y sólo en atención a lo que acaba de indicarse puede valorarse correctamente la jurisprudencia de esta Sala —sentencias de 13 de octubre de 1986, 7 de marzo de 1987, 26 de enero, 14 de marzo y 18 de julio de 1988, 31 de julio de 1989, etc.—que viene declarando que es la aprobación definitiva la verdadera resolución que culmina y pone término al procedimiento, de suerte que las precedentes aprobaciones inicial y provisional son meros actos de trámite y por tanto inimpugnables. No se desconoce con ello la competencia municipal en la materia —ya se ha dicho que se trata de una competencia compartida-: únicamente se afirma que sólo con la aprobación definitiva se obtiene el acto definitivo susceptible de impugnación con arreglo a lo dispuesto en los arts. 113.1 de la Ley de Procedimiento Administrativo y 37.1 de la Ley Jurisdiccional. Tercero. — La parte apelante alega que con el acto recurrido se revisa sin sujetarse al cauce del art. 110 de la Ley de Procedimiento Administrativo un convenio anterior pactado con el Ayuntamiento. Sin perjuicio de recordar la inadmisibilidad ya indicada será de advertir: a) La actuación de la potestad de planeamiento aspira a establecer el modelo territorial más adecuado a las exigencias del interés público de donde deriva la posibilidad de alterar ordenaciones urbanisticas establecidas con anterioridad -éste es el ius variandi-independientemente de las indemnizaciones que puedan resultar procedentes —art. 87.2 del Texto Refundido de la Ley del Suelo-; b) No resulta admisible una "disposición" de la potestad de planeamiento por vía contractual: cualquiera que sea el contenido de los acuerdos a que el Ayuntamiento haya llegado con los administrados, aquella potestad ha de actuarse para lograr la mejor ordenación posible, sin perjuicio de las consecuencias jurídicas que ya en otro terreno pueda desencadenar el apartamiento de convenios anteriores.»

O, del mismo Ponente, la STS de 18 de marzo de 1992:

«Primero. - Tienen su origen estos autos en la impugnación del Acuerdo del Consejo de Gobierno de la Comunidad de Madrid de 7-3-1985 por cuya virtud se apro- 
baba definitivamente la Revisión del Plan General de Ordenación Urbana de Madrid, siendo ya de advertir que sólo se discuten determinadas calificaciones del nuevo planeamiento invocando al respecto un "derecho adquirido de edificabilidad", un "pacto contractual" con el Ayuntamiento y en último término la desviación de poder que se atribuye, en lo que a estos autos se refiere, al acuerdo recurrido.

$Y$ ha de indicarse que el acierto de la fundamentación de la sentencia impugnada permite decidir esta apelación con unas breves observaciones.

Segundo. - El plan, elemento fundamental de nuestro ordenamiento urbanistico, dibuja el modelo territorial que se entiende, dentro de lo hacedero, más adecuado para el desarrollo de la personalidad y la convivencia. Corresponde a la Administración, con una intensa participación ciudadana para asegurar su legitimación democrática, el trazado de dicho modelo atendiendo a las exigencias del interés público: la ciudad es de todos y por tanto es el interés de la comunidad y no el de unos pocos, los propietarios de suelo, el que ha de determinar su configuración.

$Y$ es claro que la potestad administrativa de planeamiento se extiende a la reforma de éste: la naturaleza normativa de los planes, por un lado, y la necesidad de adaptarlos a las exigencias cambiantes del interés público, por otro, justifican plenamente el ius variandi que en este ámbito se reconoce a la Administración -arts. 45 y siguientes del Texto Refundido de la Ley del Suelo-.

Existe en este sentido una frondosa jurisprudencia -SS 12-5-1987, 7-11-1988, 17-6-1989, 4-5-1990, 11-2-1991, 20-1-1992, etc.-, que destaca que frente a la actuación del ius variandi, los derechos de los propietarios no son un obstáculo impidiente, aunque puedan originar indemnizaciones en los términos recogidos en el art. 87 del Texto Refundido de la Ley del Suelo de 9-4-1976 — hoy, arts. 86 y siguientes de la Ley 8/1990, de 25 de julio-.

Del propio modo, las exigencias del interés público que justifican la potestad de planeamiento $\rightarrow$ por tanto elius variandi-implican que su actuación no puede encontrar limite en los convenios que la Administración haya concluido con los administrados. Asi esta Sala viene declarando que no resulta admisible una "disposición" de la potestad de planeamiento por vía contractual: cualquiera que sea el contenido de los acuerdos a que el Ayuntamiento haya llegado con los administrados, aquella potestad ha de actuarse para lograr la mejor ordenación posible, sin perjuicio de las consecuencias que ya en otro terreno pueda desencadenar el apartamiento de convenios anteriores - SS 30 abril y 13 julio 1990, 21 septiembre y 20 diciembre 1991, 13 febrero 1992, etc..

En definitiva, los derechos de los propietarios, bien deriven del plan reformado, bien de convenios con la Administración no impiden la actuación delius variandi, independientemente de que puedan generar el derecho a una indemnización. Con ello se armonizan las exigencias del interés público y de la garantía del administrado. Es claro pues que la fundamentación de la posición del apelante —"derecho adquirido de edificabilidad", "pacto contractual"- no justifica una anulación de las calificaciones discutidas aunque pueda dar lugar a otras consecuencias jurídicas tendentes al mantenimiento de la indemnidad patrimonial que ahora no se debaten.» 
La inadmisión de la figura del Convenio es pues para el caso de que estos Convenios incidan sobre contenidos (ya sean poderes o facultades) indisponibles por las partes y en especial por la Administración -en lo relativo a las potestades de planeamiento- por vía contractual, no cuando la Administración asuma por vía convencional el compromiso de promover una alteración de planeamiento.

En la STS de 15 de diciembre de 1993, se afirma que los convenios urbanísticos si bien por sí mismo carecen de validez y obligatoriedad en cuanto se incorporan a un Plan, gozan, y corren la misma suerte que el Plan no siendo nulos mas que cuando sus determinaciones lo sean. La misma doctrina se recoge en la STS de 20 de diciembre de 1991 en la que se reitera la exigencia del interés público como fundamento de la potestad del planeamiento que no puede verse limitado por los Convenios con los administrados, con independencia de que se pueda generar un derecho de indemnización.

Una vez establecidos los límites de los Convenios, es incuestionable la potestad de la Administración actuante para perfeccionar Convenios de muy diversos contenidos del que dimanarán obligaciones, constituyendo documentos que se integran en el Plan que la Administración Pública no puede alterar y en el que los particulares deben respetar y cumplir las prestaciones a que se hubieren obligado.

\section{La evolución práctica de la figura}

Han sido escasos los análisis de la evolución que en la praxis han tenido las fórmulas convencionales como instrumentos complementarios de planeamiento. La más notable, por referirse a un Municipio pionero en la aplicación de estas técnicas y por contener una muy interesante justificación es la expuesta por Paulino MARTÍN HERNÁNDEZ en relación con la experiencia en el urbanismo madrileño ${ }^{22}$.

Agrupa este autor, que fue Secretario de la Gerencia de Urbanismo y en la actualidad Secretario del Pleno del Ayuntamiento de Madrid, en al menos cuatro familias o "generaciones" los Convenios suscritos durante el período que discurre entre los años 1981 a 1990, vinculando su nacimiento a las primeras elecciones democráticas del mes de abril de 1979 que supuso una nueva óptica para los problemas ante un planeamiento del área metropolitana

${ }^{22}$ Paulino MARTÍN HERNÁNDEZ. Los Convenios Urbanísticos. Revista de Derecho Urbanístico y Medio Ambiente no 144/1995. 
que había sobrepasado los quince años de vigencia y con una realidad de urbanizaciones deficientes o incompletas, promotores desaparecidos, cesiones no formalizadas o con cargas o atomizadas, etc., que obligaba a la adopción de fórmulas de pragmatismo de la actuación urbanística.

En este contexto el autor denomina la primera generación de Convenios como "Convenios-remedio" configurados como una fórmula de programar la gestión que permitieron remodelaciones con realojamiento, recuperaciones de espacios libres y edificaciones existentes y la defensa del PMS.

La segunda generación de Convenios se integraron en el proceso de planeamiento a los que llama "Convenio-programa", y son consecuencia de la iniciación del proceso de revisión del PGOU de Madrid ${ }^{23}$, que frente a un modelo tecnocrático pasa a proponer un planeamiento marco, participativo, flexible, y ligado a la gestión, con una formulación directa y bilateral en un primer momento y, posteriormente, con ocasión del nuevo proceso de Revisión del Plan General en septiembre de 1990, apoyándose en la publicidad de los procesos mediante los denominados concursos de suelo ${ }^{24}$, aunque esta fórmula no pasase de los planteamientos iniciales como consecuencia de las nuevas elecciones locales de 1991 y la aprobación de un nuevo Avance.

La tercera generación de Convenios utilizados por el Ayuntamiento de Madrid estuvo constituida por los denominados Convenios de Agilización urbanística para la puesta en marcha de la ejecución de los Planes Parciales del Primer Cuatrienio del PGOU ${ }^{25}$.

Finalmente durante el período objeto de análisis se inició una ambiciosa política de adquisición de suelo y construcción de viviendas incorporándose al

${ }^{23}$ El Avance del PGOU de Madrid aprobado por el Pleno en diciembre de 1981 señala como criterio de clasificación del SUE el de considerar a este suelo "campo de juego que se ofrece a la iniciativa privada para que formule sus propuestas a partir de la exposición al público, abriendo así un período de negociación que permita tanto la definitiva clasificación como la confección del programa del Plan”.

${ }^{24}$ Esta fórmula se articuló mediante la presentación, junto con el Avance del Plan, de un "Borrador de Bases del Concurso para Programación de Actuaciones Urbanísticas y ejecución de las mismas en Suelo Urbanizable no Programado del PGOU".. La adjudicación de estos concursos tenían una eficacia diferida.

${ }^{25}$ Estos Planes Parciales se encontraba estancados como consecuencia de que una de las determinaciones del Planeamiento exigía destinar el suelo con uso residencial para la construcción de VPO. 
proceso urbanizados seis ámbitos de suelo urbanizable programado mediante Convenios de Adquisición y Urbanización de suelo que preveían el establecimiento de reservas de SUENP ó SNU, a los que se aplicaba la expropiación forzosa -aunque convenida, por avenencia o adquisición amistosa ${ }^{26}$ - en la que el justiprecio se pagaba mediante entrega de una parte de aprovechamiento urbanístico -pago en especie previsto en el art. 21 del TRLS mediante la adjudicación de terrenos situados en áreas de reparto distintas a aquella en la que se expropia- fijado para el ámbito. Estos Convenios se completaban con otro, germen de la figura actualmente denominada agente urbanizador, por los cuales el urbanizador recibe el precio en aprovechamiento localizado en el ámbito de actuación ${ }^{27}$.

\section{CONCEPTO. NATURALEZA JURÍDICA}

\section{Concepto}

Se ha discutido sobre la posibilidad de conceptualizar la figura del Convenio en el ámbito del Derecho administrativo dada "la variopinta magnitud del fenómeno convencional" ${ }^{28}$, señalando que por este motivo no existen como categoría jurídica.

Una parte de la doctrina ha optado por definirlos en función de su objeto, ya sea planeamiento o gestión ${ }^{29}$. Otra la define con carácter general como Instrumentos de formalización de acuerdos entre la Administración y los particulares que sirven, fundamentalmente para pactar nuevas ordenaciones y fijar términos y condiciones de gestión y ejecución del planeamiento en vigor ${ }^{30}$.

26 Art. 24 LEF.

27 Lamentablemente Paulino Martín Hernández no ha publicado hasta la fecha la continuación del estudio de las generaciones o familias de Convenios Urbanísticos del Ayuntamiento de Madrid, que culmina, recientemente, con el Convenio de la Ciudad deportiva del Real Madrid, por algunos calificado como "Convenio-galáctico", al haberse orientado, en la segunda entrega sobre "Convenios Urbanísticos en la Actualidad", Revista de Estudios Locales CUNAL, núm. extraordinario de julio de 1999, al análisis de la legislación autonómica comparada.

28 BUSTILLO BOLADO y CUERNO LLATA "Los Convenios Urbanísticos entre Administraciones Locales y los Particulares”. Pamplona, Aranzadi, 2001, p. 83.

${ }^{29}$ DOMINGO LÓPEZ, Enrique: Los Convenios Urbanísticos en materia de planeamiento y de gestión. En Derecho Urbanístico de Andalucía. Iñigo del Guallo Castiella y Silvestre Martínez García. Marcial Pons, 2004, págs. 351-411

${ }^{30}$ Enrique SANCHEZ GOYANES: Los Convenios Urbanísticos en Derecho Urbanístico de Andalucía, El Consultor, 2004, págs. 699-721 
P. MARTÍN HERNÁNDEZ los define como "Acuerdos o manifestaciones concurrentes de las voluntades de la Administración y los operadores urbanísticos cuyo objeto es el desarrollo de la actuación urbanística en un determinado ámbito”.

Para F. A. CHOLBI CACHÁ, es una "auténtica convención negocial obligatoria, en virtud de la cual se procede a dar forma a un negocio jurídico de naturaleza patrimonial entre dos partes, Administración por una y propietarios o promotores por otra ${ }^{31 "}$.

La LOUA define a los Convenios urbanísticos como instrumentos de concertación de la actividad urbanística.

\section{Naturaleza Jurídica}

Como se ha dicho "todo contrato es convencional (el acuerdo o consentimiento entre dos o mas en el mismo objeto) pero no todo convenio es contractual"32. La jurisprudencia también ha realizado esta distinción al señalar en alguno de sus pronunciamientos, como en la STS de 9 de marzo de 2001, que:

"la figura de los convenios urbanísticos aconseja tener presente la distinción doctrinal efectuada en la teoría general del Derecho entre el contrato y la convención. La convención no contiene sólo un juego de obligaciones recíprocas o entrecruzadas (contraprestaciones) sino también compromisos paralelos de la Administración y de la Entidad mercantil que lo concierta, dirigidos a un fin coincidente y común, que tiende al aseguramiento futuro de la ejecución de la modificación del Plan cuando, en su caso, se llegue a aprobar el mismo. Tales compromisos, paralelos o convencionales, tratan de fijar el régimen de una situación futura por lo que podrían asemejarse en su estructura a las disposiciones generales. No lo hacen en su naturaleza jurídica, que sigue siendo la de un simple convenio ajeno a ellas"

La diferenciación no es meramente formal, sino que tiene un carácter sustancial para determinar cuál es la relación jurídica entre las personas intervinientes y la incidencia que tiene la legislación contractual, y directivas de

${ }^{31}$ F. A. CHOLBI CACHÁ, Los principales instrumentos de financiación procedentes del urbanismo. Pág. 470. El Consultor.2004.

${ }^{32}$ Francisco BLANC CLAVERO. "La posición jurídica del urbanizador: urbanismo concertado y contratación administrativa” Documentación Administrativa 261-262, 2002. 
la Unión europea, en materia de adjudicación, ya que no es lo mismo que su fuente sea convencional o contractual ${ }^{33}$.

Aunque se definan conjuntamente es distinta la naturaleza jurídica de los Convenios administrativo en función de los sujetos intervinientes ya que, de ser Administraciones Públicas, no tendrán, en principio, carácter contractual, a tenor del art. $3.1 \mathrm{c}$ ) de la $\mathrm{LCAP}^{34}$, como tampoco lo tienen las encomiendas de gestión que se realicen a las entidades y a las sociedades cuyo capital pertenezca totalmente a la propia Administración Pública conforme al párrafo l) del mismo precepto ${ }^{35}$, y sí tienen esta consideración, de intervenir un particular, de acuerdo con lo establecido en el art. 3.1. d) en relación con el art. 5.2 b) de la LCAP.

Este criterio matizado conforme a la nueva redacción del precepto enunciado, trae causa en la Sentencia del TSJCE de 13 de enero de 2005, por la que se declaraba, entre otros, que el art. 3 apartado 1 letra c) anterior del TRLCAP incumple determinadas directivas europeas ${ }^{36}$ al excluir de forma absoluta del ámbito de aplicación del TRLCAP, los convenios de colaboración que celebren las Administraciones Públicas con las demás entidades públicas y, por tanto, también los convenios que constituyan contratos públicos a efectos de dichas Directivas.

La citada Sentencia tiene como antecedente la Sentencia "Teckal", del TSJCE de 18 de noviembre de 1999, por la que se considera que estaba sujeto a los procedimientos de adjudicación de contratos de suministro un Convenio suscrito entre el Ayuntamiento de Viano y una mancomunidad constituida por con varios municipios (AGAC), para la gestión de los servicios de energía y medio ambiente.

\footnotetext{
${ }^{33}$ En este sentido se ha tratado por la doctrina de excluir el convenio de adjudicación de una actuación urbanizadora -en concreto el supuesto de agente urbanizador- de la aplicación de las directivas comunitarias y legislación española de contratación pública para lo cual ha dedicado todo un número monográfico la revista Actualidad Administrativa, núm. 261-262 de septiembre 2001-abril 2002.

${ }^{34}$ Redactado conforme al Real Decreto ley 5/2005, de 11 de marzo (BOE 14 de marzo).

${ }^{35}$ Este apartado ha sido añadido tan bien por el art. 34 del Real Decreto ley 5/2005, de 11 de marzo.

${ }^{36}$ Directivas 93/36/CEE del Consejo de y 93/37/CEE del Consejo de 14 de junio de 1993.
} 
Como consecuencia pues de estas Sentencias se ha procedido mediante el RD legislativo 5/2005 de 11 de marzo a dar una nueva redacción al el párrafo c) del apartado 1 del art. 3 del TRLCAP en virtud de la cual la exclusión de la legislación de contratos sólo se aplica a los Convenios de colaboración interadministrativo "siempre que la materia sobre la que verse no sea objeto de un contrato de obras, de suministro de consultoría y asistencia o servicios, o que siendo objeto de tales contratos su importe sea inferior respectivamente a las cuantías que se especifican en los art. 135.1, 177.2 y 203.2".Es decir, que se encuentren en supuestos cuya cuantía requiera la publicidad comunitaria que, en materia de obras no puede superar los 5.358.153€, en suministro $750.000 €$, y, en materia de consultoría, asistencia y servicios no exceda de $750.000 €$, añadiendo que estarán excluidos los Convenios interadministrativos siempre que la materia sobre la que versen no sea objeto de un contrato de obras, de suministro, de consultoría y asistencia o de servicios o que siendo objeto de tales contratos su importe sea inferior, respectivamente, a las cuantías que exijan publicidad comunitaria.

\subsection{Convenios Interadministrativos.}

Al quedar excluidos, en los términos expresados, de la aplicación de la Ley de Contratos su fuente normativa se recoge en el art. 6 de la LRJPAC que concreta el contenido del Convenio, prevé la posibilidad de creación de un órgano mixto de control para resolver los problemas de interpretación y de cumplimiento y la posibilidad de creación de una organización común en forma de consorcio o sociedad mercantil (aquí el Convenio sería meramente instrumental o preparatorio de la persona jurídica consorcial o mercantil que se proyecta) ${ }^{37}$. El art. 8 de la misma Ley restringe el contenido del Convenio al marco de competencias de las Administraciones que intervienen, que no pueden renunciar, en aras del Convenio, a sus competencias propias y residencia las cuestiones litigiosas referentes a aquél en la jurisdicción contencioso-administrativa. El art. 9 de la misma Ley declara aplicable a la Administración Local en la materia la legislación básica de régimen local, quedando la propia Ley como de aplicación supletoria.

\footnotetext{
${ }^{37}$ La Constitución y régimen jurídico de los Consorcios está regulada expresamente en Andalucía por la Ley 7/1993, de 27 de julio, de Demarcación Municipal de Andalucía, teniendo por objeto la realización de actuaciones conjuntas, coordinación de actividades y consecución de fines de interés común entre Entidades Locales y cualquier otra Administración Pública o entidad privada sin ánimo de lucro que persiga fines de interés público concurrentes con los de la Administraciones Públicas.
} 
Con respecto a la legislación básica de régimen local, con referencia exclusiva a las disposiciones que mencionan al Convenio, y no a las que regulan las relaciones de la Administración Local con otras Administraciones. El art. 57 de la LBRL meramente indica que la cooperación de la Administración Local con las Administraciones del Estado o de la Comunidad Autónoma puede articularse mediante Convenios Administrativo. El art. 70 del TRRL ${ }^{38}$ dispone la colaboración de la Administración Local en la realización de obras o gestión de servicios del Estado, incluidos los de la Seguridad Social, mediante convenio. Finalmente el art. 72 del mismo texto legal prohíbe a la Administración Local costear servicios del Estado o de la Comunidad Autónoma, salvo mediante fórmulas de colaboración voluntaria a la prestación de los mismos (o sea, puede utilizarse, como una de estas fórmulas, el convenio, siempre que no se limite a la financiación, sino que también abarque a la colaboración en la gestión).

En este ámbito de la Administración Local la Comunidad Autónoma de Andalucía, cuenta con la Ley 7/1993 de 27 de julio de Demarcación Municipal, cuyos arts. 37 a 42 son aplicables a la figura de Convenio. Son especialidades de esta Ley, respecto de la Legislación General examinada, las siguientes: por una parte prevé la posibilidad de traspaso de personal, que quedaría, de ser funcionario, en situación de Comisión de Servicio en el órgano a que se adscriba y en situación de servicio activo en el órgano de procedencia (evidentemente se silencia cualquier referencia al personal laboral, por haber éste de sujetarse a este respecto al Estatuto de los Trabajadores y Disposiciones Complementarias, especialmente a las normas que garantizan la estabilidad del trabajador frente a los cambios afectantes al empresario) y por otra parte se prevé también la posibilidad de adscripción de bienes y medios patrimoniales mediante cesión de uso.

\subsection{Convenios urbanísticos entre la Administración y los particulares}

Pese a los esfuerzos doctrinales para apartar estos Convenios del ámbito de la contratación administrativa al considerarlos negocios y contratos excluidos de acuerdo con el art. 3.1.d) de la LCAP, es mayoritaria la posición que considera que estos convenios tienen la naturaleza de un contrato administrativo especial conforme a lo establecido en el art. 5.1.b) cuyo régimen jurídico se establece en el art. 7 de la legislación de contratos.

${ }^{38}$ De conformidad con la disposición final séptima del TRRL, este artículo no tiene naturaleza de básico. 
Y ello ya que el art. $3.1 \mathrm{~d}$ ) señalado acota el ámbito objetivo y subjetivo de este tipo de Convenio con un marcado acento restrictivo, derivado sin duda del hecho fundamental de que el modo general y normal de relación sinalagmática y bilateral de las personas privadas con la administración es el contrato, siendo el convenio que escapa en general de la normativa de la Ley de Contratos de las Administraciones públicas (sólo se aplican sus principios para resolver dudas y lagunas) según su art. 3.2 una mera excepción. Según dicho artículo, para que pueda celebrarse el Convenio y excluirse del ámbito de aplicación de la LCAP se precisan acumulativamente las siguientes circunstancias: a) Debe estar regulado por norma específica, b) Su objeto no debe estar comprendido dentro de los contratos regulados por la Ley de Contratos de las Administraciones Públicas o por normas administrativas especiales, y lo cierto es que, como hemos visto, la legislación urbanística regula esta materia por lo que no se puede considerar excluido de la LCAP.

Por tanto los Convenios urbanísticos se han configurado como un Contrato administrativo especial conforme a lo establecido en el art. 5.2 b) de la LCAP dado que la relación regulada convencionalmente está calificada expresamente como administrativa, se encuentra prevista y dispuesta en una ley formal y guarda relación directa o inmediata con una responsabilidad-función pública, es decir, con el giro o tráfico propio de la Administración urbanísti$\mathrm{ca}^{39}$, cuyo régimen jurídico, de acuerdo con lo establecido en el art. 7 LCAP, en cuanto a su preparación, adjudicación, efectos y extinción se regirán con carácter preferente por sus propias normas y, supletoriamente por la LCAP.

Hay que tener en cuenta el papel relevante que hoy en día tiene los Contratos y Convenios entre la Administración y los particulares y que están siendo resaltados especialmente por la doctrina administrativa alemana que ha destacado esta figura para la solución de problemáticas complejas, en relaciones jurídicas que abarcan momentos temporales diversos, lo que supone una función complementaria y sustitutoria de la "actuación soberana unilateral" que asegura una mayor aceptación ${ }^{40}$. Para esta doctrina el contrato adminis-

\footnotetext{
${ }^{39}$ La expresión «giro o tráfico» administrativo acoge posición de E. GARCíA DE ENTERRÍA que utiliza este criterio para delimitar el ámbito conceptual del Derecho administrativo, su carácter estatutario. Cuando la Administración contratante actúa dentro de su «giro o tráfico» debe presidir esa actuación el Derecho administrativo y, por consiguiente, los contratos que se celebren deben ser administrativos. Con ello se elude la fórmula que la relacionaba con el «desenvolvimiento regular de un servicio público», ante la crisis y renovación que están viviendo los servicios públicos en la actualidad.

${ }^{40}$ Walter Krebs: Contratos y Convenios entre la Administración y particulares. Documentación administrativa.
} 
trativo "se encuentra en la intersección de dos entramados de relaciones: como expresión del Estado cooperativo dentro de la actuación estatal consensuada y como regulación jurídico-obligacional dentro de las actuaciones jurídico-formales. Tiene por un lado, una posición jurídica extraordinaria por su forma jurídica y por su carácter jurídico-obligacional y, por otro, se configura como modelo especial de la creación del Derecho" 41 .

En esta dirección la LOUA considera un deber para las Administraciones con competencia en materia de ordenación urbanística el facilitar y promover la iniciativa privada ${ }^{42}$ que se materializará a través de los convenios urbanísticos con particulares con la finalidad de establecer los términos de la colaboración para el mejor y más eficaz desarrollo de la actividad urbanística.

\section{Algunas consideraciones sobre la aplicación del régimen contractual a los Convenios urbanísticos}

3.1. Incidencia de la legislación de contratos en la legislación urbanística

Como hemos dicho, los Convenios urbanísticos entre la Administración y los particulares tienen la consideración de Contrato administrativo especial conforme a lo establecido en el art. 5.2 b) de la LCAP cuyo régimen jurídico, de acuerdo con el art. 7 LCAP, en cuanto a su preparación, adjudicación, efectos y extinción se regirán con carácter preferente por sus propias normas y, supletoriamente por la LCAP.

También hemos visto las normas propias de los Convenios urbanísticos de planeamiento y gestión y su sujeción a los principios de transparencia y publicidad. Ahora tenemos que analizar, aunque sea someramente, la incidencia de la legislación contractual, de aplicación supletoria, a la regulación urbanística, que está siendo objeto de gran debate doctrinal a raíz de la Sentencia del TJ-

Para este autor el verdadero significado de los contratos de la Administración con los particulares, no está ya en la posible sustitución de un mandato soberano unilateral ni en la competencia consensuada que puede hacer a los mandatos imperativos sino que se encuentra "donde el Estado no puede cumplir sus funciones o no puede hacerlo del modo pretendido sin la cooperación voluntaria de fuerzas sociales organizadas o no organizadas. De ahí que el contrato administrativo se dé especialmente en el Derecho urbanístico, en la protección del medio ambiente y en amplios sectores de la asistencia social".

${ }^{41}$ W. Krebs, Documentación administrativa. pág. 60.

42 Art. 5.2. 
CE de 12-7-2001 recaída en el asunto "Scala" y su impacto en el ordenamiento español, recaído fundamentalmente en la STSJ de la Comunidad Valenciana de 1-10-2002 en cuyo pronunciamiento se sostiene:

“... que la adjudicación a un particular de un plan de urbanización que permite a su titular la realización directa de una obra pública, es un contrato de obra, y ha de respetarse en cualquier caso la normativa comunitaria sobre contratación administrativa, y por ello entiende que la normativa urbanistica italiana, que permite al titular del suelo que solicita una licencia urbanística, o al titular de un plan, realizarlo por sí mismo, sin cumplir la normativa comunitaria en relación con la contratación es contraria a la Directiva 93/1997/ CEE, de 14 de junio de 1993, sobre Coordinación de los Procedimientos de Adjudicación de los Contratos Públicos de Obras...”

Pese a que la cuestión de inconstitucionalidad planteada por el TSJ de Valencia al TC fue declarada inadmisible ${ }^{43}$, lo cierto es que en el Auto dictado no se plantea el problema planteado de compatibilidad entre la Ley reguladora de la Actividad Urbanística de Valencia y la LCAP "que se presupone", sino de inobservancia de aquella disposición, errando el TSJ, a juicio del TC, al comparar preceptos legales que regulan instituciones distintas cuales son la cesión de contratos y la subrogación

En todo caso la persona natural o jurídica que suscriba el Convenio con la Administración debe contar con capacidad de obrar y solvencia económica, financiera, técnica o profesional conforme al art. 15 de la LCAP, lo que puede entrañar dificultades en caso de que no cuente con la titularidad del suelo o disponga de un patrimonio social insuficiente, y no debe estar incurso en las prohibiciones para contratar cuyas circunstancias se detallan en el art. 20 .

Especial problemática tiene la aplicación de los principios de contratación para suscribir los Convenios urbanísticos, en especial la libre concurrencia e igualdad de los procedimientos de adjudicación, dada la imposibilidad material de liberalizar el suelo, así como la tramitación de los expedientes por los procedimientos de concurso, con los correspondientes Pliegos de Condiciones técnico-económicas, que solamente pueden plantearse en la fase de planeamiento, cuya viabilidad se suscita en los supuestos de gestión indirecta de la urbanización u obra pública.

En todo caso hay que tener en cuenta el carácter participativo de la elaboración de los planes urbanísticos y la publicidad de sus normas y planos

${ }^{43}$ Auto del TC núm. 133/2002, de 16 de julio. 
como elementos que pueden considerarse, en relación con la libre concurrencia e igualdad que informa los procedimientos contractuales, de forma intrínseco.

\subsection{Las garantías del cumplimiento de los Convenios}

En principio, la legislación urbanística, suele precisar la presentación de garantías o cauciones de forma previa, en algunas autorizaciones, necesarias para la ejecución del desarrollo urbanístico. Sometiendo habitualmente a licencia previa, el derecho de edificar, a urbanizar, al aprovechamiento urbanístico, etc.

Existen de otra parte, dentro de la LOUA otras imposiciones y exigencias de caución, y son aquellas que hacen relación a la naturaleza convenida en la resolución de actos y actuaciones de esta naturaleza, que asegure el cumplimiento de lo convenido, y ello, porque en muchas de estas actuaciones, lo acordado, no deja de presentar o implicar, por parte de la actuación municipal, el ejercicio de potestades administrativas, que podrían verse lesionadas y con ello, el interés público, quedando de esta forma, salvaguardados de posibilidades no deseadas, pero posibles, de tal suerte, que pasamos a analizar, ambos apartados.

Por tanto es necesario que los Convenios contemplen la garantía necesaria y conveniente, dada la diversidad de ejecuciones llevadas a cabo mediante estos instrumentos, como caución, tanto de la correcta ejecución de un contrato, que no implica el ejercicio de poderes exorbitantes por parte de la administración al tratarse de una imposición legal para la contratación administrativa en la LCAP.

\section{RÉGIMEN JURÍDICO. LOS PRINCIPIOS DE TRANSPARENCIA Y PUBLICIDAD}

Tanto los Convenios de planeamiento como de gestión se rigen por los principios comunes de transparencia y publicidad, en las fases de "tramitación, celebración y cumplimiento", añadiéndose, para los convenios de gestión, también la aplicación de estos principios en la fase de "negociación"44.

\footnotetext{
${ }^{44}$ En tanto se regula reglamentariamente Hay que entender la transparencia y publicidad en la negociación de los Convenios en los mismos términos que establece el TRLCAP al regular los procedimientos negociados.
} 
Su plasmación concreta, en lo relativo a su tramitación, se encuentra técnicamente en la publicación de los mismos en el $\mathrm{BOP}^{45}$ previa inclusión en el correspondiente registro administrativo y la preceptiva información pública antes de su aprobación ${ }^{46}$.

Por otro lado, y, en el ámbito del Régimen Local, y aunque conforme a la distribución competencial establecida en la LBRL, son dos órganos distintos los que aprueban los instrumentos de Gestión ${ }^{47}$, y Planeamiento, corresponde al Pleno ${ }^{48}$, la aprobación de ambos al poner fin a la tramitación municipal.

Por tanto la aprobación definitiva del Convenio requiere un primer acuerdo, equivalente a la aprobación inicial, para someter el documento a información pública, por un plazo no inferior al mes los de planeamiento ${ }^{49} \mathrm{y}$, de veinte días, los de gestión ${ }^{50}$ y, tras la misma y oídas e informadas las alegaciones el acuerdo definitivo de aprobación, su inscripción en el registro administrativo y publicación en el Boletín Oficial correspondiente.

La regulación de este Registro administrativo se ha establecido mediante Decreto 2/2004, de 7 de enero, por el que se regulan los registros administrativos de instrumentos de planeamiento, de convenios urbanísticos y de los bienes y espacios catalogados y se crea el registro autonómico de la Consejería de Obras Públicas y Transportes de la Junta de Andalucía.

En cuanto a la inscripción en el Registro de la Propiedad de los Convenios Urbanísticos, de acuerdo con el Real Decreto 1093/1997, de 4 de julio, por el que se aprueban las normas complementarias al Reglamento para la ejecución de la Ley Hipotecaria sobre inscripción en el Registro de la Propiedad de actos de naturaleza urbanística, (BOE 23 de julio de 1997), se efectuará mediante certificación administrativa del órgano urbanístico actuante que cumpla los requisitos establecidos en el art. 2 de ésta disposición siempre que los

\footnotetext{
${ }^{45}$ Art. 41.3 .

${ }^{46}$ Art. 39.2.

${ }^{47}$ Art. $\left.21.1 \mathrm{j}\right)$.

${ }^{48}$ Art. 22.2 c).

49 Art. $32.12^{\underline{a}}$.

${ }^{50}$ Art. $95 \cdot 2 \cdot 2^{\underline{a}}$
} 
referidos actos modifiquen, desde luego o en el futuro, el dominio o cualquier otro derecho real sobre fincas determinadas o la descripción de éstas, pudiendo llevarse a cabo loas segregaciones o modificaciones hipotecarias que procedan para la determinación registral de la finca que es objeto de cesión de acuerdo con lo establecido en el art. 30.4 de las normas complementarias reseñadas.

Finalmente, y en cuanto al régimen de impugnación de acuerdos, sin perjuicio de los recursos administrativos pertinentes se plantea una dualidad en cuanto al órgano jurisdiccional competente para conocer de las demandas que se presenten frente a los Convenios ya que, de ser frente a un Convenio de Planeamiento, y pese a no incluirse como instrumentos de planeamiento, están incluidos dentro del Título I (instrumentos de Ordenación) Capítulo IV que se refiere a la "elaboración, aprobación y sus efectos, la vigencia y la innovación de instrumentos de planeamiento" por lo que correspondería su conocimiento a la Sala de lo Contencioso-administrativo ${ }^{51}$, al ser competente en "cualquier clase de instrumentos de planeamiento urbanístico". Sin embargo los Convenios de Gestión están incluidos en el Título IV que se refiere a la ejecución del planeamiento siendo competente los Juzgados de lo Contencioso-administrativo ${ }^{52}$.

\section{TIPOLOGÍA DE LOS CONVENIOS INTERADMINISTRATIVOS ENTRE DOS O MÁS ADMINISTRACIONES PÚBLICAS EN LA LEGISLACIÓN DE ANDALUCÍA}

Esta fórmula convencional ha experimentado en los últimos años un crecimiento notable merced a las nuevas técnicas de organización y funcionamiento del aparato administrativo, las cuales son resultantes de la moderna concepción instrumental de la Administración pública como maquinaria al servicio de los intereses generales. En el ámbito que nos incumbe -territorial y urbanístico-, y sin perjuicio de los Convenios interadministrativos atípicos que se puedan suscribir, se pueden distinguir los siguientes:

5.1. Convenios interadministrativos para la prestación de asistencia técnica y administrativa en materia de ordenación urbanística

La LOUA se refiere expresamente a los Convenios Interadministrativos en relación con la Cooperación y colaboración en su art. 4 para establecer que:

\footnotetext{
${ }^{51}$ LRJCA: art. 10.1 a).

${ }^{52}$ LJJCA: art. 8.
} 
"Las Administraciones Públicas y las entidades a ellas adscritas o dependientes de las mismas en el ejercicio de la actividad urbanistica se regirán por los principios de cooperación y colaboración.

A estos efectos y en el ámbito de sus respectivas competencias podrán celebrar convenios de colaboración con la finalidad, entre otras, de prestación de asistencia y cooperación a las Entidades Locales en materias tales como la ordenación urbanistica, ejecución de los instrumentos de planeamiento, intervención de la edificación y uso del suelo, y protección de la legalidad".

Por otro lado el art. 92 posibilita que en el marco de la Colaboración interadministrativa se puedan suscribir Convenios en los términos autorizados por la legislación de régimen jurídico de las Administraciones Públicas y de régimen local y por la LOUA, aunque parece circunscribirlos, en principio, a la financiación de los órganos comarcales o supramunicipales para la prestación de asistencia técnica y administrativa a los municipios en materia de ordenación urbanística, en todos o algunos de los siguientes fines:

a) Redacción, gestión y ejecución del planeamiento.

b) Consultoría y asistencia técnica.

c) Prestación de servicios.

d) Actividad urbanizadora y edificatoria, gestión y explotación de las obras resultantes.

\section{2. Convenios interadministrativos para la gestión patrimonial}

La LPAP, aunque de aplicación limitada a las CCAA y EELL en virtud de los títulos competenciales, recoge la posibilidad de celebrar Convenios patrimoniales y urbanísticos entre la AGE, sus organismos públicos vinculados a ella o dependientes, con otras Administraciones públicas o personas jurídicas de derecho público o de derecho privado pertenecientes al sector público con el fin de ordenar las relaciones de carácter patrimonial y urbanístico entre ellas en un determinado ámbito o realizar actuaciones comprendidas en la LPAP en relación con los bienes y derechos de sus respectivos patrimonios ${ }^{53}$. La regulación establecida prevé que estos Convenios se limiten a recoger compromisos de actuación futura de las partes, revistiendo el carácter de acuerdos marco o protocolos generales, o prever la realización de operaciones concretas y determinadas, en cuyo caso podrán ser inmediatamente ejecutivos y obligatorios para las partes considerándose la totalidad de las operaciones contempladas en el mismo un úni-

53 Art. 186-188. 
co negocio complejo, que, previo el cumplimiento de los requisitos procedimentales establecidos, y una vez firmados, constituirán título suficiente para inscribirse en el Registro de la Propiedad u otros registros.

\section{3. Convenios interadministrativos de Planeamiento}

A diferencia de la redacción establecida para los Convenios de Gestión, el art. 30.1 define como sujetos de estos Convenios a "la Administración de la Junta de Andalucía y los Ayuntamientos, así como los organismos adscritos o dependientes de una y otros, podrán suscribir entre sí y con otras Administraciones y sus organismos convenios interadministrativos" siendo el objeto "definir de común acuerdo y en el ámbito de sus respectivas competencias los términos en que deba preverse en el planeamiento urbanístico la realización de los intereses públicos que gestionen.

Estos Convenios se rigen en todo lo no previsto en la LOUA por la LRJPA, no siendo de aplicación lo establecido para la tramitación de los Convenios entre particulares en el ap. 2 del art. 30 aunque sí los principios de transparencia y publicidad.

5.4. Convenios interadministrativos para la actividad de ejecución. Consorcios urbanísticos

El art. 90.2 c) de la LOUA autoriza, con carácter general, a las Administraciones Públicas para suscribir convenios de colaboración con otras administraciones, organismos de ellas dependientes o entidades por ellas fundadas o controladas para las actividades de ejecución.

En este punto habrá que determinar, caso por caso, si no nos encontramos ante una actividad contractual y por tanto sujeta al TRLCAP de acuerdo con la nueva definición del art. 3.1 apartados c) y l) como consecuencia de las sentencias recaídas en el ámbito europeo arriba comentadas.

En cuanto a los Consorcios que puedan constituir entre ellas, el art. 93.2 prevé que se integren personas (jurídicas) privadas previa suscripción de convenio pero será la prevista en la legislación general -sin fines de lucro- y en ningún caso podrá ser mayoritaria.

\section{5. Convenios interadministrativos para la Gestión Integrada}

Ya sea a través del instrumento de planeamiento o mediante el procedimiento de delimitación de unidades de ejecución la LOUA prevé la ejecución 
mediante las denominadas Áreas de Gestión integrada que comportará la coordinación e integración de las acciones de la Administración de la Junta de Andalucía y los Municipios y en su caso restantes administraciones ${ }^{54}$, habilitándose la organización consorcial en los términos que "libremente" acuerden las Administraciones.

Esta forma de Consorcio se puede prever directamente en el instrumento de planeamiento o constituir voluntariamente por los municipios afectados, la Administración de la Junta de Andalucía y las restantes administraciones afectadas o interesadas.

5. 6. Convenios interadministrativos para la ejecución de actuaciones de interés autonómico

Recientemente, junto a la materia de ordenación urbanística también habría que incluir los aspectos que en materia de ordenación territorial se prevén en la reciente reforma de la $\operatorname{LOTA}^{55}$ en virtud de la cual para el desarrollo de las actuaciones de interés autonómico, que junto a las actuaciones sectoriales y territoriales que se expresan puede implicar la implantación de usos productivos, dotaciones, o cualesquiera otros análogos que precisen desarrollo urbanístico y vincularán directamente al planeamiento que deberá incorporar sus determinaciones con ocasión de la siguiente innovación urbanística, podrán celebrarse convenios de colaboración con el municipio o municipios afectados, en los que podrán concertarse los términos de la actuación y su ejecución.

Pese a lo discutible de esta figura desde la perspectiva de la autonomía municipal y las críticas que puedan realizarse lo cierto es que se constituye como un instrumento muy potente que posibilita, una vez aprobado, el juego de actuaciones territoriales y urbanísticas por parte de la administración autonómica de forma inmediata, y cuya aplicación deberá realizarse de forma concertada con la Administración municipal.

\footnotetext{
${ }^{54}$ LOUA Art 144.
}

${ }^{55} \mathrm{El}$ art. 43 de la Ley 3/2004, d e28 de diciembre, ha añadido un nuevo Título IV a la LOTA denominado "De las actuaciones de interés autonómico" incorporando los art. 38 sobre la Declaración de Interés autonómico y el art. 39 sobre los Proyectos de Actuación. En el apartado 4 de este último precepto se recoge que " Para el desarrollo de las actuaciones a que se refiere el presente artículo podrán celebrarse convenios de colaboración con el municipio o municipios afectados, en los que podrán concertarse los términos de la actuación y su ejecución”. 
En todo caso, la figura de los Convenios interadministrativos se ha extendido a la mayoría de las actuaciones en las que está en juego intereses concurrentes, en especial de infraestructuras o patrimoniales, de las Administraciones implicadas promoviéndose en estos momentos un gran número de ellos vinculados a la construcción de viviendas protegidas ${ }^{56}$ que podemos considerar dentro de los tipos expuestos como Convenios patrimoniales al implicar la gestión de los PPS de las Administraciones intervinientes.

\section{TIPOLOGÍA DE LOS CONVENIOS ENTRE LA ADMINISTRA- CIÓN Y LOS PARTICULARES}

El segundo tipo de convenio, el convenio de la Administración con personas privadas, se encuentra regulado en la LOUA la cual, como se ha dicho, establece su régimen jurídico propio, rigiéndose supletoriamente, en cuanto a su preparación, adjudicación, efectos y extinción por la LCAP. En cualquier caso ninguno de estos Convenios puede considerarse, a tenor de lo establecido en el art. 88 de la LRJPAC una forma de terminación convencional del procedimiento.

Como es sabido, salvo peculiaridades que puedan darse, el Convenio Urbanístico tiene dos variantes: el Convenio para el planeamiento y el Convenio para la gestión. La STS de 15 de marzo de 1997, recogida en la STS de 9 de marzo de 2001, 31 de enero de 2002 ha subrayado las diferencias entre Convenio de Planeamiento y Gestión al afirmar que:

"A diferencia de los Convenios de gestión urbanistica, para la gestión o ejecución de un planeamiento ya aprobado, los Convenios de planeamiento, como el que se enjuicia, constituyen una manifestación de una actuación convencional frecuente en las Administraciones Públicas, que tiene por objeto la preparación de una modificación o revisión del planeamiento en vigor.

Aunque el convenio o acto convencional en cuestión se dirige a preparar y poner en marcha una alteración del planeamiento, constituye una realidad o acto sustantivo independiente del procedimiento de modificación o revisión del Plan, que no puede ser considerado como acto de trámite a efectos del artículo 37.1 en relación con el 82, c) de la Ley de la Jurisdicción Contencioso-Administrativa".

\footnotetext{
${ }^{56}$ La Conferencia Sectorial del Suelo y la Vivienda celebrada el 22 de enero de 2003 concluye con la firma de un Acuerdo de mínimos por parte de 12 Comunidades Autónomas (las gobernadas por el PP, más Cataluña, Canarias, Ceuta y Melilla) e incluye entre sus propuestas la de incentivar en primer lugar la firma de convenios interadministrativos que precisen el destino futuro de los suelos patrimoniales en atención a los distintos intereses en juego y fijen las cesiones para usos públicos y los procedimientos de venta de los sobrantes
} 
Entre la tipología que con carácter general se ha establecido para los Convenios, partiendo de la distinción reseñada sobre la base del soporte legal previamente establecido entre la administración y los particulares, que se pueden encontrar en la legislación urbanística andaluza, podemos señalar los siguientes:

\section{Convenios urbanísticos de planeamiento}

El objeto de estos Convenios según enuncia el art. 30.2 estará relacionado con "la formación o innovación de un instrumento de planeamiento", pudiendo suscribirse de forma conjunta o separada "con cualesquiera personas, públicas o privadas, sean o no propietarias de suelo.

Las reglas de aplicación quedan fijadas en:

1.- Vinculación únicamente para iniciar y tramitar el pertinente procedimiento.

2.- Que la cesión del aprovechamiento urbanístico correspondiente a la Administración urbanística, bien en suelo o cantidad sustitutoria en metálico (que en su caso incluirá la valoración realizada por la Administración), se integrará en el patrimonio público de suelo correspondiente.

3 En el acuerdo aprobatorio, que se sustanciará tras la información pública en el $\mathrm{BOP}^{57}$, contendrá como mínimo se identificará a los otorgantes y señalará su ámbito, objeto y plazo de vigencia situación y emplazamiento de los terrenos afectados, y será publicado tras su firma por la Administración urbanística e se incluirá en un registro público de carácter administrativo.

4. La tramitación, celebración y cumplimiento de los convenios regulados en este artículo se regirán por los principios de transparencia y publicidad.

La Convenios de planeamiento pueden tener dos tipos de objeto: por un lado la formación de un instrumento de planeamiento y, por otro, la innovación (que puede implicar una modificación o revisión del instrumento de planeamiento) de alguna de las determinaciones del instrumento de planeamiento vigente, ya sea en cuanto uso, localización de espacios libres o dotaciones, tipologías etc. que no se encuentren excluidas en el art. 36.1 de la LOUA.

${ }^{57}$ Art. 39. 
1.1. Convenio para la formación de un instrumento de planeamiento

La expresión "formación" de un instrumento tiene que ver con las determinaciones que se establezcan para la "formulación" del mismo, cuya iniciación puede suscitarse por los particulares en el caso de Planes de sectorización, Planes Parciales, Planes Especiales y Estudios de Detalle, y, también, durante la tramitación de los Planes Generales de Ordenación urbanística y los Planes de Ordenación Intermunicipal, al objeto de lograr un "mejor y más eficaz desarrollo de la actividad urbanística" ${ }^{58}$.

La posibilidad de convenir la formación de un determinado instrumento de planeamiento va a suscitar una nueva modalidad de convenios no sólo en orden a la financiación de los instrumentos de desarrollo sino también en cuanto a la ordenación de determinados sectores durante la tramitación del planeamiento general.

\subsection{Convenio para la innovación de un instrumento de planeamiento}

Hasta hoy estos son los convenios más frecuentes en especial al tener por objeto la modificación puntual siendo muy amplia y variada la casuística de los mismos.

El procedimiento es el establecido en el art. 36.2, excepto para la delimitación de nuevas unidades de ejecución que se realizarán por el procedimiento establecido en el art. 18.1 de la LOUA, sin perjuicio de que tengan también la consideración de innovación de instrumentos de planeamiento.

\section{Convenios urbanísticos de gestión}

Vienen regulados en el art. 95 de la LOUA, al señalar la posibilidad de celebrarlos entre las Administraciones autonómica y los Ayuntamientos, conjunta o separadamente con personas públicas y privadas, tengan éstas o no la condición de propietarios de los terrenos afectados, al objeto de "determinar las condiciones y los términos de la gestión y ejecución del planeamiento urbanístico en vigor en el momento de la celebración del convenio", rigiéndose por los mismos principios de transparencia y publicidad, y de acuerdo con las siguientes reglas:

58 Art. 5.2. 
1. El destino de la cesión del aprovechamiento urbanístico será el PPS.

2. Los convenios que tengan por finalidad la elección o sustitución del sistema de ejecución, la fijación de sus bases, o incluyan entre sus compromisos algunos de los objetos establecidos para la reparcelación, según lo dispuesto en el artículo 100.2 de esta Ley, deberán ser sometidos antes de su firma a información pública por un plazo de veinte días.

3. El acuerdo de aprobación del convenio, que, al menos, identificará a los otorgantes y señalará su ámbito, objeto y plazo de vigencia, será publicado por la Administración tras su firma en los términos previstos en el art. 41.3 de la LOUA. Dicho acuerdo, junto con el convenio, se incluirán en un registro público de carácter administrativo.

Entre los tipos específicos de Convenios de Gestión que se recogen expresamente en la LOUA, sin mencionar los referidos a los compromisos que constituyan objeto de la reparcelación conforme al art. 100.2 de la LOUA, ni los que se recogen en materia de expropiación forzosa en la $\mathrm{LEF}^{59}$, podemos señalar los siguientes:

2.1. Convenio para la determinación del sistema de actuación y forma de gestión

Esta previsto en el art. 108.2 de la LOUA que la Administración para el caso de que estén de acuerdo los propietarios que representen más del 50\% de los terrenos afectados para determinar el sistema de actuación (privada o pública $)^{60}$, y forma de gestión de la actuación (directa o indirecta) ${ }^{61}$ en el caso de la expropiación o de cooperación ${ }^{62}$.

${ }^{59}$ En materia expropiatoria se recogen al menos tres tipos de acuerdos de voluntades:

El primero de ellos tiene lugar antes del inicio del procedimiento cuyo objeto no es fijar el justiprecio sino evitar que sea necesario el inicio del expediente y posterior fijación de un justiprecio que encajaría dentro de los contratos privados establecidos en el art. 5.3 LCAP.

Otro supuesto de acuerdo de voluntades es el que tiene su base en el art. 24 de la LEF y 25 a 27 de su Reglamento las partes tienen amplio margen de maniobra para decidir sobre la cuantía del justiprecio y sobre el modo de pago, admitiéndose incluso el pago en especie con muy variados contenidos y formulaciones, lo que les dota en muchos casos de una estructura sinalagmática similar a la permuta, aunque el hecho de que surjan en el seno de un procedimiento expropiatorio y la finalidad perseguida (que trasciende del mero intercambio patrimonial y que consiste precisamente en poner fin al expediente) impide que puedan confundirse sin más con tales contratos.

${ }^{60}$ LOUA: art. 107.

${ }^{61}$ LOUA: art. 116.

${ }^{62}$ LOUA: art. 123.1 B) 
2.2. Convenio para la sustitución del sistema de actuación por compensación

En lo relativo a la sustitución del sistema de actuación por compensación el art. 109 de la LOUA establece la posibilidad de finalización por Convenio en el que podrá preverse, en las condiciones que al efecto se precisen, la continuación en el proceso urbanizador y edificatorio por parte de los propietarios que así lo deseen, no obstante la declaración del incumplimiento y la sustitución del sistema de actuación. También podrán celebrarse convenios preparatorios de la terminación, incluso convencional, del procedimiento.

En estos casos la elección del sistema de actuación que deba sustituir al de compensación se efectuará con arreglo a los siguientes criterios:

- si la sustitución derive de procedimiento de declaración de incumplimiento iniciado a instancia de parte interesada en asumir la gestión de la actuación urbanizadora, procederá el establecimiento del sistema de expropiación mediante gestión indirecta.

- cualquiera que sea la forma de iniciación del procedimiento de declaración de incumplimiento, será preferente el sistema de expropiación mediante gestión directa cuando exista urgente necesidad pública declarada por el municipio de incorporar los terrenos al patrimonio público de suelo o de destinarlos a la construcción de viviendas en régimen de protección pública $u$ otros usos de interés social.

2.3. Convenios para la terminación del procedimiento de declaración de incumplimiento del sistema de actuación por compensación

Así mismo se prevé en el art. 110 el procedimiento para la declaración de incumplimiento y sustitución del sistema de actuación por compensación que se iniciará de oficio o a instancia de parte cuya terminación podrá ser o preparada mediante convenios urbanísticos con los propietarios que, no obstante la sustitución del sistema de actuación, deseen continuar incorporados al proceso urbanizador y edificatorio, o, sustituir la resolución administrativa unilateral, mediante convenio urbanístico suscrito con todos los propietarios afectados y las demás personas incorporadas al sistema de actuación sustituido.

\subsection{Convenios relativos a la asunción de gastos de urbanización}

El art. 113.1 establece cuales son los conceptos susceptibles de considerarse gastos de urbanización a los efectos de imponer al propietario la carga 
real de levantamiento de la parte proporcional de los costes de urbanización prevé, expresamente en el ap. k), el de "cualesquiera otro asumido mediante Convenio urbanístico o establecidos en la correspondiente concesión administrativa".

2.5. Convenio para el pago en especie del justiprecio en el sistema de expropiación.

Está previsto en el art. 120.2 que el pago del justiprecio pueda producirse, de acuerdo con el expropiado, mediante la entrega o permuta de otras fincas, parcelas o solares, no necesariamente localizada en la unidad de ejecución, perteneciente a la administración actuante o al beneficiario de la expropiación.

Consideramos que esta modalidad de pago deberá revestir la forma de Convenio urbanístico, sin perjuicio de que de no existir acuerdo no proceda su formalización y se acuda al procedimiento previsto en esta disposición con intervención de la Comisión Provincial de Valoraciones.

2.6. Convenio de adjudicación de la actuación urbanizadora al agente urbanizador

La gestión indirecta de la actividad de ejecución en el sistema de expropiación se realiza por concesión estableciéndose en el art. 119.1 3º) de la LOUA que la adjudicación se formalizará mediante el correspondiente Convenio urbanístico excluyéndolo expresamente de la necesidad de someter a información pública o trámite alguno. Esta adjudicación conlleva el deber de presentar el proyecto de urbanización que asuma las condiciones de adjudicación así como la iniciación de la actividad de ejecución o del procedimiento expropiatorio.

\subsection{Convenio para la fijación de las Bases del Sistema de Cooperación}

Ya sea propietario único o varios propietarios, la LOUA prevé la posibilidad de fijar las Bases del Sistema mediante Convenio urbanístico en el art. 123.3, pudiendo extenderse esta participación en el sistema posteriormente, mediante la constitución de una Asociación administrativa.

2.8. Convenio para el aplazamiento de pago de los gastos de urbanización en el Sistema de Cooperación

Está permitida la posibilidad de que la Administración mediante Convenio, cuando las circunstancias así lo aconseje y en las condiciones que se de- 
terminen y de acuerdo con la entidad o sociedad que asuma la gestión, convenga con los propietarios el aplazamiento del pago de los gastos de urbanización de acuerdo con lo establecido en el art. 124.b) de la LOUA.

2.9. Convenio por el que se establece procedimientos sustitutorios al pago en metálico del precio de la ejecución de obras

$\mathrm{El}$ art. 127.2 de la LOUA recoge una fórmula sustitutoria al pago en metálico del precio de ejecución de obra en el sistema de cooperación que requiere su previa valoración y que consiste en la enajenación de suelo edificable a favor de la empresa urbanizadora o la adjudicación a la misma de aprovechamiento lucrativo, edificabilidad o solares resultantes de la urbanización.

2.10. Convenio para el establecimiento del sistema de compensación .

La LOUA establece en su art. 138 en relación con el art. 131, que cuando la totalidad de propietarios esté dispuesta a asumir conjuntamente la entera actividad de ejecución, por sí o mediante la participación de agente urbanizador, conforme a las condiciones libremente pactadas y exista conformidad entre los propietarios y el municipio se podrá suscribir un Convenio para el establecimiento del Sistema que seguirá, salvo regulación específica o participación de agente urbanizador, la misma regulación que para el supuesto de propietario único

2.11. Convenio para la sustitución de las cesiones patrimoniales por el pago en metálico

Se trata de una variedad o especialidad del Convenio anterior, en el que se especifica, de acuerdo con lo establecido en el art. 72 c) de la LOUA, la sustitución de las cesiones patrimoniales correspondientes a la Administración por pago en metálico, que deberá valorarse por la Administración, e integrar el PPS.

\subsection{Convenio para la cesión gratuita de dotaciones}

El art. 143.2 b) prevé expresamente la cesión gratuita de dotaciones mediante Convenio en las actuaciones urbanizadoras no integradas equivalentes a las actuaciones asistemáticas.

En este sentido el art. 177 de la LOUA posibilita la inscripción en el Registro de la Propiedad de aquellos convenios urbanísticos que supongan la alteración de la descripción registral, del dominio o de cualquier otro derecho real de la finca o fincas objeto del mismo. 


\section{CONSIDERACIONES FINALES}

Aunque la ley regula los Convenios de Planeamiento y Gestión de forma diferenciada, la realidad es que la mayoría de los Convenios que se efectúan en el ámbito urbanístico son mixtos o atípicos. Hay que considerar, en todo caso a los Convenios de Planeamiento como convenios marco ya que los mismos pueden regular aspectos relativos a la gestión como es la cesión de aprovechamientos urbanísticos.

Los Convenios urbanísticos interadministrativos no pueden tener ya por objeto contratos sometidos a las Directivas europeas, ya sea de obras, servicios o suministros, en la medida en que interviene un poder adjudicador. Tampoco las sociedades públicas instrumentales de una determinada Administración pueden recibir directamente encargos de Administraciones públicas distintas.

Muchas de las teorías dominantes en la segunda mitad del siglo XX, basadas en la planificación estricta y centralizada que imponen zonificaciones cerradas y usos estrictamente separados están siendo sometidas a discusión por intelectuales de difícil clasificación ideológica que plantean estrategias de gestión urbana basadas en la comunidad, la diversidad de usos e inclusive la concentración de densidad (y pluralidad) sobre el principio del "orden espontáneo" y un funcionamiento saludable del entorno urbano.

Los Convenios urbanísticos entre la Administración y los particulares pueden ser un instrumento adecuado para la solución consensuada de los problemas de una organización compleja como es la Ciudad. Se trata de una planificación que sin despreciar los vuelos, descienda a las calles, que contemple, coloquialmente, la ubicación de la "tienda de la esquina", localice las encrucijadas, los puntos de encuentro, para "mantener y mejorar las condiciones de la calidad de vida en Andalucía" (art. 3.1 a) LOUA).

\section{BIBLIOGRAFÍA}

\section{A) De carácter general}

Derecho Urbanístico de Andalucía. Iñigo del Guayo Castiella y Silvestre Martínez García (directores). Marcial Pons, 2003. Págs. 351-411.

Derecho Urbanístico de Andalucía. Enrique Sánchez Goyanes (director). El Consultor. 2004. págs. 699-721. 
Comentarios a la LOUA. Venancio Gutiérrez Colomina, Ángel Cabral González-Sicilia. Thomson-Aranzadi. 2004

Ley de Ordenación Urbanística de Andalucía, Antonio Baena González. Editorial Montecorvo. 2003. Pág. 343.

\section{B) De carácter específico.}

CANO MURCIA, A: Teoría y práctica del Convenio Urbanístico. Doctrina, legislación, jurisprudencia y formularios. Editorial ARANZADI, 1996, 347.

BUSTILLO BOLADO, R.O. y CUERNO LLATA, J.R.: Los Convenios Urbanísticos entre Administraciones locales y Particulares. Editorial ARANZADI, 1997, 237 PÁGS.

HUERGO LORA, A: "los Convenios Urbanísticos, Editorial CIVITAS, Madrid,, 1998. 251 págs.

\section{C) Artículos de revistas.}

CORRAL GARCÍA. E. “Los Convenios urbanísticos”. El Consultor nº 14/1995, págs. 2.047 y ss.

LÓPEZ PELLICER, A “Naturaleza, supuestos y límites de los Convenios Urbanísticos”. Revista de Derecho Urbanístico” nº 146/1996, pág. 97 y ss.

PAULINO MARTÍN HERNÁNDEZ: Los Convenios urbanísticos. Revista de derecho urbanístico y medio ambiente $\mathrm{n}^{\circ}$ 144/1995.

Los Convenios urbanísticas en la actualidad. CUNAL Págs. 313 y ss.

Francisco BLANC CLAVERO. "La posición jurídica del urbanizador: urbanismo concertado y contratación administrativa” Documentación Administrativa 261-262, 2002

FRANCISCO BLANC CLAVERO. "La posición jurídica del urbanizador: urbanismo concertado y contratación administrativa” Documentación Administrativa 261-262, 2002

AROZAMENA SIERRA, J. “Algunas consideraciones sobre la institución contractual y el urbanismo: Los llamados Convenios Urbanísticos. Revista de

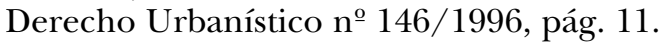

ALONSO, M. J.; "Responsabilidad patrimonial de la Administración por incumplimiento de los Convenios Urbanísticos en la reciente Jurisprudencia del Tribunal Supremo”, Revista EALA, núms.. 271-272/1996. pág. 853 y ss.

WALTER KREBS: Contratos y Convenios entre la Administración y particulares. Documentación administrativa. 


\section{Documentos en Internet.}

"The ephemeral city" Joel Kotkin. www.metropolismag.com

"The Rise of ephemeral city" Joel Kotkin. Metropolis Magazine www.metropolismag.com

"Cities:Places Sacred, Safe and Busy" Joel Kotkin. www.joelkotkin.com

"How Simcity Influences Planning Culture" Daniel G. Lobo. www.americancity.org

"Technology and Tolerance: The Importance of Diversity to High-Technology of Growth". Richard Florida. Carnegie Mellon University. Center of Urban an Metropolitan Policy. www.brookings.edu 